\title{
終戦直後の都市計画法改正検討に関する研究(その 1)：
}

\section{5 年 都市計画法改正案と地方計画及都市計画法案について}

A STUDY ON THE DELIBERATION PROCESS OF REVISE

THE URBAN PLANNING LAW IN THE IMMEDIATE POSTWAR PERIOD PART 1:

BILL TO REVISE THE URBAN PLANNING LAW AND DRAFT OF REGIONAL PLANNING LAW IN 1945

\author{
藤賀雅人*1, 岡辺重雄*2 \\ Masato FUJIGA and Shigeo OKABE
}

\begin{abstract}
This paper studied the deliberation process of revise the urban planning law directly after World War II. The Home Ministry recognized the necessity of phased planning system to solve prewar urban planning issues. Initially, revisions of necessary parts in urban planning law were discussed. However, a new law system was to be created as an ideal draft including regional planning for responding to the coordination between cities. This draft was to organize regional planning led by the central government and urban planning led by regional government, and to suggest a unified framework from the coordination between cities to architectural regulation.
\end{abstract}

Keywords : Urban Planning Law, Regional Planning Law, War-Damage Reconstruction, Land Readjustment, Architectural Regulation 都市計画法, 地方計画法, 戦災復興事業, 土地区画整理, 建築規制

\section{1. はじめに}

\section{1-1.研究の背景と本稿の目的}

終戦を迎え、内務省国土局では戦災復興事業に向けた準備が早急 に進められた。担当者等は、復興事業実施に向けた論点整理として、 『戦災復興事業課題』を作成していたが ${ }^{1)}$ 、この中では、復興事業 に必要な応急対応よりも、恒久対策となる都市政策のあり方につい て網羅的な課題整理が試みられた。その内容は、中央計画・地方計 画・都市計画といった段階的な計画体系を模索する記述や、建築政 策の改善など、建築・都市計画について広範にわたっている。こう した側面は終戦直後の中央行政において、戦前の都市計画・建築行 政の課題を改めることが積極的に検討されたと理解できる。また、 法制面についても、(1)地方計画法の設定、(2)特別都市計画法の設定、 (3)都市計画法と建築法の改正、(4)土地法の 4 点が課題として示され ており、戦災復興事業への対応及び戦後の建築・都市空間を考える 上で、計画理論の体系的な改善と、抜本的な法改正が必要と認識さ れていたことが窺える。

これまでの終戦直後の都市計画思想や建築法・都市計画法の改正 検討を扱う都市計画史研究をみれば、戦災復興都市計画の思想を提 示するものとして越澤や石田の研究があり ${ }^{2)}$ 、筆者等の研究も、戦 災復興計画標準の検討過程を明らかにしてきた ${ }^{3)}$ 。法制史研究をみ れば、建築法について市街地建築物法の改正から、建築法草案の提
案に至るまでのプロセスを明らかにし ${ }^{4)}$ 、市街地の土地法として検 討が進められた宅地法の内容と都市計画との関係性を考察した研究 5) が行われてきたが、都市計画法の改正を主眼とした検討実態につ いては、資料の制約から十分な研究が行われてこなかった。そのた め、終戦直後、中央において都市計画関連法規の検討がなされてい たのか、また、そうであれば、どのような計画思想のもと、法改正・ 制定が思考されていたのか、この点 は明らかにされてこなかった。

こうした学術的背景の中、筆者等 は内務省が主導して検討を進めた 『地方計画法案・都市計画改正法案 立案準備関係』資料 (Fig1) を入手 し ${ }^{6)}$ 、この時期の都市計画関連法規 の改正動向について考察を行うこ とが可能となった。本研究では、こ うした資料を活用し、復興事業に向 けた検討時の時代背景を把握しつ つ、都市計画関連法規の改正提案を 整理し、当時の計画思想と制度設計 の検討実態を明らかにすることで、 戦前の都市計画法の課題点と、戦後

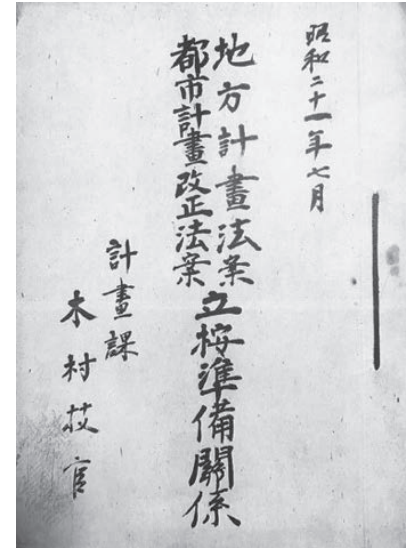

Fig1 Files draft of regional and urban planning law 『地方計画法案・都市計画改 正法案立案準備関係』

\footnotetext{
*1 工学院大学建築学部まちづくり学科 准教授・博士(学術)

*2 福山市立大学都市経営学部都市経営学科 教授 - 博士 (工学)
}

Assoc. Prof., Dept. of Urban Design and Planning, School of Architecture, Kogakuin University, Ph.D.

Prof., Dept. of Urban Management, School of Urban Management, Fukuyama City University, Ph.D. in Eng. 
の都市計画行政を進める上での法規提案の意義を明確化することを 目的としている。

さて、『地方計画法案・都市計画改正法案立案準備関係』によれば、 終戦直後の都市計画法の改正は地方計画法制定と合わせて検討が進 められたとされる。当初、都市計画法単独の改正が検討され、その 後、地方計画法及都市計画法案として、地方計画と都市計画を合わ せた法案が作成されている。その後、再度、都市計画法の改正案作 りが行われ、こうした幾つかの法案作成が試みられた後、地方計画 法案及び都市計画改正法案の基礎案作成を進める準備会が内務省国 土局内に設置され、検討が進められたという。

本稿では、こうした過程の中でも、戦災地復興計画基本方針制定 及び戦災復興院設立前に当たる、1945（昭和 20）年の都市計画法改 正案と地方計画及都市計画法案の考察を進めることとする。この 2 案を考察する意図は、内務省国土局内において、戦災復興事業の準 備を行いつつ、都市計画法の改正をどのように思考したのか、この 点を明らかにするためであり、復興事業への対応及び戦後の都市計 画理論を知る上で有益な過程と位置付けることができるためである。 また、地方計画及び都市計画の内容を明らかにし、これら 2 つ計 画理論を法制化する発展的思考を把握する意味もある。つまりは、 この過程を詳細に考察することは、戦前の都市計画の課題を知るこ とに繋がるとともに、終戦直後の中央における計画理論の思考と、 都市計画関連法の改正・制定の視点を明確化する意義がある。

なお、関連する既往研究として、地方計画については、戦前の地 方計画論を扱うものは多数あり、地方計画と外地の地域制との関係 を考察するもの ${ }^{7)}$ 、終戦前の地方計画法案と関東地方計画要綱案と の関係を考察した研究も行われているが ${ }^{8)}$ 、終戦直後の内務省によ る都市計画法改正等との関係を考察した研究は行われていない。

\section{1-2.研究の方法}

本研究は以下の手順で進める。まず、内務省において作成された 『戦災復興事業課題』における地方計画、都市計画に関連する課題 を精査するとともに、法制関連の課題事項の把握を行うことで、終 戦直後の復興事業及び都市政策上の課題を整理する。こうした上で、 1945 (昭和 20) 年 10 月 1 日都市計画法改正案 (以下、10月 1 日案 と略す)、同 10 月 2 日都市計画法改正案 (以下、10月 2 日案と略 す)の内容を把握し、終戦直後の都市計画法改正の視点を把握する。 最後に、同 10 月 20 日作成の地方計画及都市計画法案の内容を考察 することで、中央における地方計画及び都市計画の思考を把握する とともに、戦後の都市計画法改正の趣旨を明確化する。

\section{2.『戦災復興事業課題』における地方計画・都市計画・法制課題}

内務省では、戦後の都市政策・復興事業を進める上で、戦前の課 題事項を含めて『戦災復興事業課題』として整理を行った。法制面 での課題として、戦災復興事業の事業手法となる土地区画整理に法 的根拠をもたらすために特別都市計画法を制定すること、関連して 復興事業を進めるための土地法についても検討する必要が認識され た ${ }^{9)}$ 。これに加えて、地方計画法の設定と、従来の都市計画法及び 建築法の改正が必要であることが示されている。地方計画法につい ては、「沿線建築禁止」が対応項目として記述され、都市計画法・建 築法改正については、「堅牢建築物禁止区域、建築負担台帳、受益者
負担性ノ合理化、都市改造規定」が課題として記されており、両計 画に対して復興事業を進める上での配慮点が記載されている。

これら制度立案の前提に位置付けられる計画思想の記述を見れば、 恒久対策は中央計画、地方計画、都市計画の 3 つを段階的に進める こととされている。中央計画は大都市の規制や国立施設の計画とい った中央主導の計画、軍港や新興工業都市等の機能変更など、国策 とすべき対応が位置付けられている。これに続いて、地方計画が示 されるが、ここでは、地方計画区域や土地利用計画を課題として挙 げており、「立体的地方計画/設定」として防空施設の積極的利用や、 軍用地の農耕地化、工場の教育機関化など、戦後対応の記述がなさ れた。また、農業、鉱業、観光保勝地域制など、「気象、風土、災害 史ヨリ見タル都市立地問題」を考慮した対応を行うための計画であ ることが示されている。加えて、地方交通の整備に向けた事項、衛 星都市論や水道問題といった地方市町村の共同処理問題等が記され ていることから見ても、地方計画が、特定の都市の計画ではなく、 複数の都市・地域に渡る計画や、都市間の調整を念頭に置いた計画 として想定されていたことが窥える ${ }^{10)}$ 。

都市計画は、最も多くの課題整理がなされた項目であり、総則で は都市計画を中央計画、地方計画と調整することを記している。続 く地域地区問題では、「用途地域制〉指導精神ノ再検討」が示され、 具体的な地域や地区名として「業務地域工業地域の快適問題」「農業 地域制」「緑地地域ノ設定」「鉱業地域制問題」「海水沿場地区」「交 通地区」「菜園住宅地区」「原始産業地区等ノ特別地区自由設定」「風 紀地区問題」といった区域設定や課題点が網羅的に整理されている。 また、「容積地域制(仮称) ノ合理化」「空地地区制度ノ再検討」「高 度地区助成問題」といった、形態規制のあり方についても見直しの 必要性を示している。この他にも、都心・副都心・近隣中心の課題 として、公共建築物の立地や工業・商業地域と住宅の関係性が課題 とされており、緑地問題では、緑地地域設定や緑地面積、最低限度 の緑地計画がまとめられた。交通問題では鉄道等の交通機関や道路 幅員等の課題整理がなされている。

以上のように、地域地区制をはじめとした都市計画の改善と中央 計画、地方計画といった段階的な計画体系の構築を進める必要性が 内務省内で認識されており、こうした点を改善するためにも法改 正・法制定が必要とされていた。

\section{1945 (昭和20) 年 都市計画法改正案の検討 \\ 3-1.1945（昭和20）年 都市計画法改正案の検討時期}

『地方計画法案・都市計画改正法案立案準備関係』によれば、最 も早く改正案が作成されたのは、1945（昭和20）年10月1日、同2日 の都市計画法改正案となる。同時期、内務省では戦災復興事業に向 けた都市計画基本方針案の整理や各種計画標準の素案づくりも進め られており、基本方針の素案に当たる戦災地都市計画基本方針がま とめられたのも同10月8日である11)。つまりは、内務省国土局にお いて戦災復興事業を進める基本方針の検討と並行して、都市計画法 の改正案作成が進められていたことになる。これは、内務省内にお いて、都市計画法の改正の必要性が大きく、優先的に検討作業が行 われていたと捉えるべきであろう。戦災地都市計画基本方針では、 閣議決定された戦災地復興計画基本方針には無い、法制的措置が設 けられており、ここでも 
(一)都市計画ノ実施八都市計画法二依ルノ外其ノ実施 容易ナラシムル為特別都市計画法习設クルコト

(二) 戦災地其ノ他ノ都市計画二伴七必要ナル规定习設ク ル為都市計画法及市街地建築物法ノ改正ヨナスコト

と示されている ${ }^{12)}$ 。ここからも、特別都市計画法の制定と、都市計 画法・市街地建築物法の改正が、戦災復興事業の実施、戦後の都市・ 建築行政として必須の事項と考えられていたことが確認できる。

\section{3-2.1945（昭和 20）年 都市計画法改正案の内容}

具体に 10 月 1 日案と 10 月 2 日案の内容を考察していく (Table1)。 両改正案ともに、従来の都市計画法をべースとして、部分的に修正 する箇所を記述・整理する形式で作成されており、抜本的な改正で はなく、不足を改める趣旨の改正案作りが進められている。10月 1 日案、10月 2 日案の修正箇所は必ずしも同じではなく、考えられる 改正パターンを複数作成し、その後の本格的な都市計画法改正の検 討に備える試案作りとして検討が行われたと見ることができる ${ }^{13)}$ 。

\section{(1) 10 月 1 日都市計画法改正案}

10 月 1 日案は、旧都市計画法の第九条から第十二条、これに加え て第十六条について修正が必要としている。

第十条では緑地保持のため、都市計画区域内外に緑地地区を指定 することができるとしており、戦災復興事業に際して、計画標準等 で示す予定の土地利用・緑地系統の計画について、都市計画法内に 記述することで、法的根拠を持たせようとしている ${ }^{14)}$ 。一方で、第 十一条ノ三では、都市計画区域内外に亘って、工場規制区域を設定 できるとし、工場の無秩序な建設の禁止のため、制限が可能とされ ている。『戦災復興事業課題』においても「工場地域指定卜住宅問題」

「業務地域工業地域」が課題とされていたことから見て ${ }^{15)}$ 、工業系 施設と他の用途の区域分けを明確化するために設定が考えられたの だろう。以上のように、必要に応じた地域地区の区分追加が目指さ れている。

最も大きな改正は、第十二条に見られる。ここでは、土地区画整 理の運用について都市計画法内に規定することを目指し、第三項以 降に関連事項を多く追記しょうとしている。各項の末尾に特別法第 六条、同七条など括弧書きがなされているように、同時に検討が進 められていたと考えられる特別都市計画法の関連項目で、常時の都 市計画においても規定す心゙き項目については都市計画法を改正する ことで、位置付けることが目指されている ${ }^{16)}$ 。具体的には、換地処 分や土地所有者への対応など、事業実務に係る事項のほか、過小宅 地への対応を記述し、小画地の発生禁止を示すなど、当時の都市計 画課題への対応に触れている ${ }^{17)}$ 。

このほか、道路・広場・港湾 - 公園等の施設造成を都市計画の施 設として明確化するとともに（第十六条第二項）、公共用地を活用 した都市計画事業の負担について条項を加えるなど(第九条第二項)、 都市計画の範囲を明確に寸る改正が考えられている。

\section{（2）10 月 2 日都市計画法改正案}

10 月 1 日案が戦災復興事業の進捗に向けた改正に主眼を置いてい たのに対して、10月2日案は第一条の都市計画の趣旨において「防 空」の文言を省き、第三条の都市計画事業の決定についても「内閣 ノ認可ヨ受クベシ」といった記述を消去するなど、戦時対応により
加えられた防空の目的と中央主体の都市計画体制を改めようとして おり、都市計画法全体にわたって改正を行う趣旨が強い案となって いる。

地域地区制に対して、10月1日案同様に緑地地区（第十条）と工 場規制区域（第十一条三）の設定がなされているが、加えて、第 十一条ノ四には、災害の被災後に建築規制区域を主務大臣が指定す ることができるとされている。これは、「都市計画上必要アルト キ」という条件があるように、復興事業進捗を円滑にするために設 定するものと考えられる年)。また、地区として明確な区分は示され ていないが、第十一条ノ六では「美観保持上必要アルトキハ・・

(中略) ・ ・美観习害スル広告其ノ他ノ工作物二付之力゙除却・改造 其ノ他必要ナル措置ヨ命ズルコトヨ得」として、美観に配慮した措 置について積極的な記述となっている。このように、地域地区の拡 充や、必要と考えられる建築規制・用途規制の設定を目指している 点が10月 2 日案の最大の特徴である。

土地区画整理事業について触れる第十二条について、この案でも 多くの追記がなされているが、換地処分や補償に関する事項など、 事業実施の為というよりも、地権者等の権利について触れる内容が 多くなっている。小画地の対応についても、宅地の適正規模保持の ため、栜令によって分筆を制限できるとしており、状況に応じた制 限を可能とする内容となっている。これに加えて、10月1日案と同 様に、道路・広場・港湾・公園等の施設造成を都市計画の施設とし て明確化することを改正点とした。

\section{3-3. 小結}

内務省では、戦災復興事業に向けた基本方針や計画標準、特別都 市計画法の作成を行いつつ、同時に都市計画法の改正についても検 討が進められていた。10月1日案は、戦災復興事業への対応を意識 し、土地区画整理を都市計画法に位置付けることに主眼をおいた改 正案となっていたが、10月2日案では、内閣の認可や防空といった 戦時対応を改めるとともに、建築規制区域を加えるなど、復興事業 を進める上での規制区域も新たに提案されている。

2つの改正案に共通する事項として、緑地地区や工場規制区域な ど、戦災復興で進めることが想定された地域地区区分の設定と戦前 のゾーニングの不足を補う区域を新設することが想定され、土地区 画整理事業の実施についても都市計画法内に位置付けるべき内容の 模索がなされていた。また、都市計画の施設を明確に位置付けるこ とが目指された。これらの改正点は、戦災復興事業を進める上で重 要な事項を都市計画法内に位置付ける意味があったと共に、土地区 画整理による基盤整備を進めることで、都市環境を整備していくこ とが、当時としては重要事項であったことを表している。以上のよ うな、戦災復興事業を念頭におきつつ、従来の都市計画法の不足点 を改める試案づくりが第一段階として進められた。

\section{4. 地方計画及都市計画法案の提案}

従来の都市計画法を改正することを検討した後、内務省内では地 方計画及都市計画法案が作成され、1945（昭和 20）年 10 月 20 日に は、四章と附則からなる素案が完成している (Table2)。この法案で は、地方計画と都市計画が並列に設けられつつも、関係性を持って 計画・事業進捗を規定していくことが目指されている。やや曖昧な 
Table1 Bill to revise the urban planning law in 1945 1945年 都市計画法改正案の内容

\begin{tabular}{|c|c|c|c|}
\hline & $\begin{array}{l}\text { 旧都市計画法 } \\
\text { 1940年4月1日 } \\
\end{array}$ & $\begin{array}{c}\text { 都市計画法改正案 ※2 } \\
\text { 1945年10月1日 } \\
\end{array}$ & $\begin{array}{c}\text { 都市計画法改正案 } \\
\text { 1945年10月2日 } \\
\end{array}$ \\
\hline 第一条 & 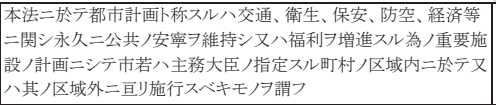 & 変更無し & 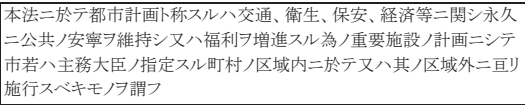 \\
\hline 第三条 & $\begin{array}{l}\text { 都市計画、都市計画事業及毎年度執行スベキ都市計画事業八都 } \\
\text { 市計画委員会ノ議习経テ主務大臣之ヨ決定シ内閣ノ認可习受クベ } \\
\text { シ }\end{array}$ & 変更無L & $\begin{array}{l}\text { 都市計画、都市計画事業及毎年度執行スベキ都市計画事業八都市 } \\
\text { 計画員会/議ヨ経テ主務大臣之ᄏ決定ス }\end{array}$ \\
\hline $\begin{array}{l}\text { 第九条 } \\
\text { 第二項 }\end{array}$ & ( & 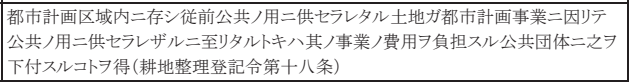 & 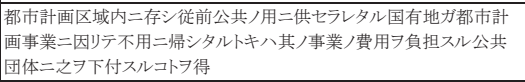 \\
\hline $\begin{array}{l}\text { 第十条 } \\
\text { 第二項 }\end{array}$ & 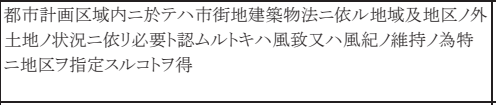 & $\begin{array}{l}\text { 都市計画区域内ニ於テ必要卜認ムルトキハ緑地保持ノ為特二緑地地区ヨ指定スルコ } \\
\text { 卜ヨ得 } \\
\text { 主務大臣必要卜認ムルトキハ関係市町村ノ意見习聞キ前項ノ区域外二亘り緑地地区 } \\
\text { 指定スルコト习得 } \\
\end{array}$ & $\begin{array}{l}\text { 主務大臣都市計画区域内二於テ都市計画上必要卜認ムルトキハハ緑地 } \\
\text { 保持/為都市計画区内人外二亘リ特二緑地地区定スルコト得 }\end{array}$ \\
\hline 第十一条 & 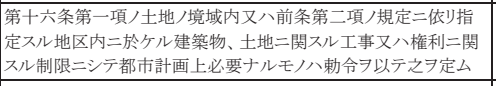 & 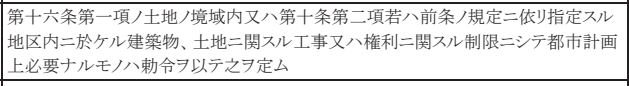 & 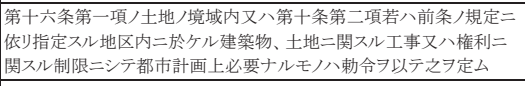 \\
\hline 第十一条ノ二 & 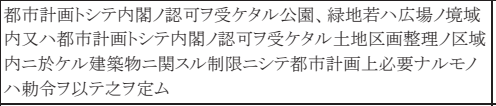 & 変更無L & 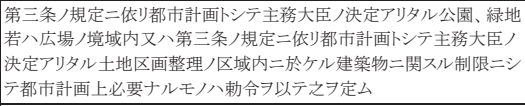 \\
\hline 第十一条ノ三 & - & 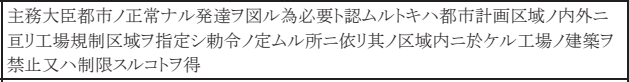 & $\begin{array}{l}\text { 主務大臣都市ノ正当ナル発達ヨ図ル為必要卜認ムルトキハ都市計画 } \\
\text { 区域ノ内外二亘リ工場規制区域ヨ指定スルコトヨ得 }\end{array}$ \\
\hline 第十一条/四 & - & ( & $\begin{array}{l}\text { 主務大臣都市計画区域内/相当地域ガ災害ヨ蒙リタル場合二於テ都 } \\
\text { 市計画上必要アルトン地方長官ヨシテ建築規制区域ヨ指定セシム } \\
\text { ルコトヨ得 }\end{array}$ \\
\hline 第十一条/五 & - & - & 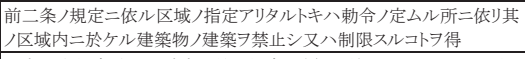 \\
\hline 第十一条ノ六 & - & 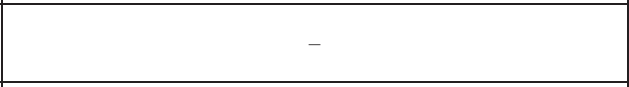 & 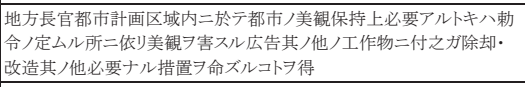 \\
\hline $\begin{array}{l}\text { 第十二条 } \\
\text { 第二項 }\end{array}$ & $\begin{array}{l}\text { 前項ノ土地区画整理二関シテハ本法二別段ノ定アル場合ヨ除クノ } \\
\text { 外地整理法引漼用ス }\end{array}$ & 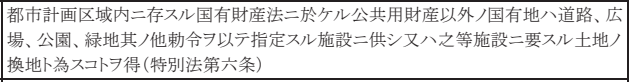 & 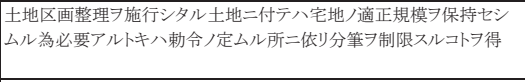 \\
\hline $\begin{array}{l}\text { 第十二条 } \\
\text { 第三項 } \\
\text { 以降 } ※ 1\end{array}$ & - & 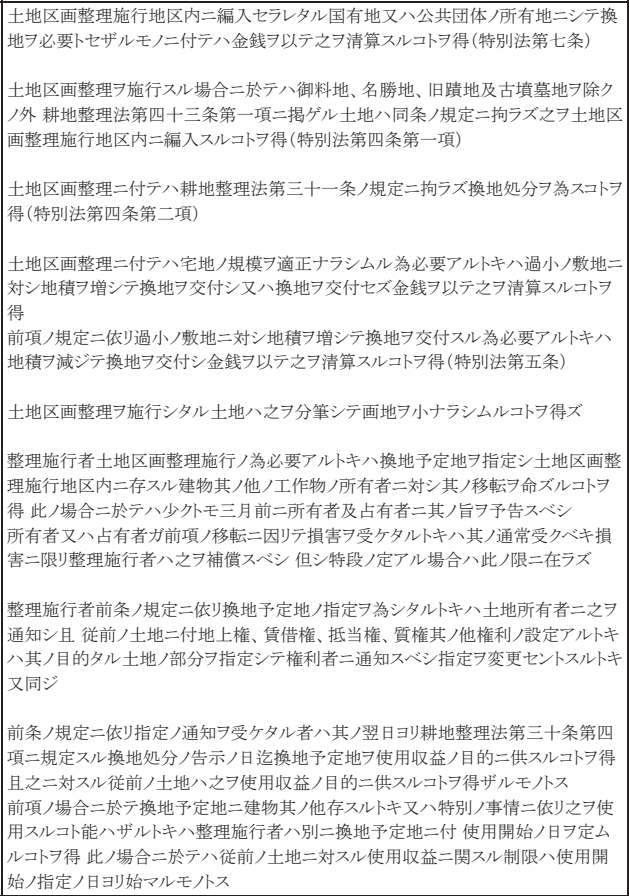 & 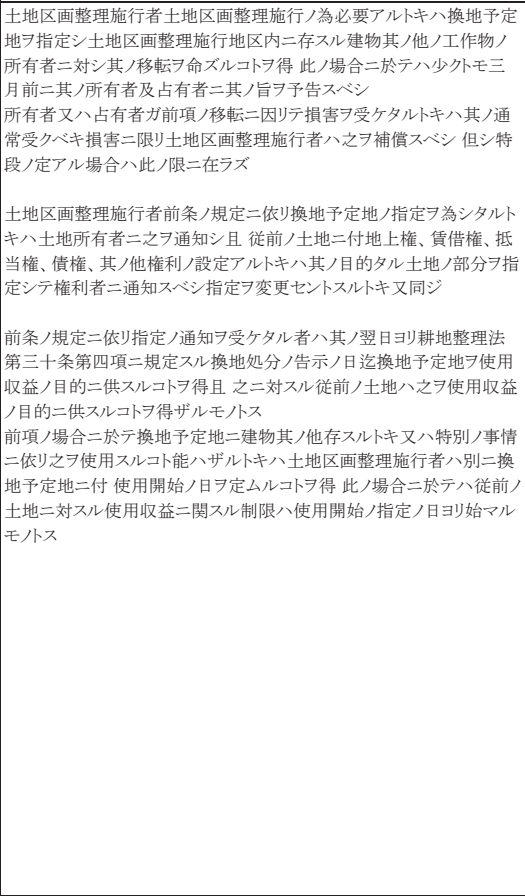 \\
\hline $\begin{array}{l}\text { 第十三条 } \\
\text { 第一項 }\end{array}$ & 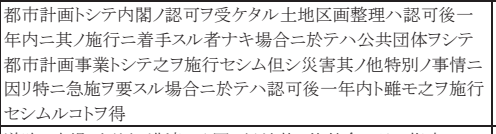 & 変更無L & 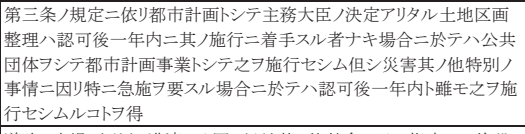 \\
\hline $\begin{array}{l}\text { 第十六条 } \\
\text { 第一項 }\end{array}$ & 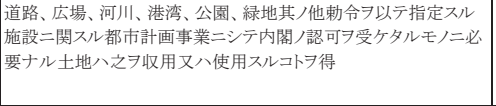 & 変更無L & 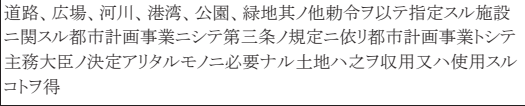 \\
\hline $\begin{array}{l}\text { 第十六条 } \\
\text { 第二項 }\end{array}$ & $\begin{array}{l}\text { 前項土地附近ノ土地ニシテ都市計画事業トシテノノ建築敷地造成二| } \\
\text { 必要ナルモノハ䡃令ノ定ムルル所ニ依リ之ヨ収用又ハ使用スルコト } \\
\text { ヨ得 }\end{array}$ & \begin{tabular}{|l} 
都市計画区域内二於テ前条第一項二揭どル施設ヨ造成セントスルトキハ都市計画ノ \\
施設トシテそ為スベシ
\end{tabular} & $\begin{array}{l}\text { 都市計画区域内二於テ前条第一項ニ掲ゲル施設ヨ造成セントスルトキ } \\
\text { 八都市計画/施設トシンそタ為スベシ }\end{array}$ \\
\hline $\begin{array}{l}\text { 第十六条 } \\
\text { 第三項 }\end{array}$ & - & 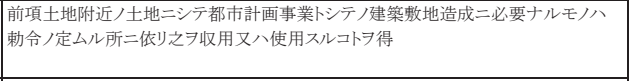 & 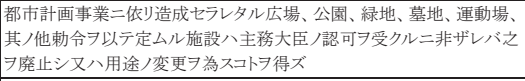 \\
\hline 第十九条 & $\begin{array}{l}\text { 第十六条又ハ第十七条ノ規定二依ル収用又ハ使用二付テハ第三 } \\
\text { 条ノ規定二依ル都市計画/認可ヨ以テ土地収用法二依ル事業ノ } \\
\text { 認可卜看做ス }\end{array}$ & 変更無L & 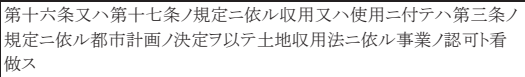 \\
\hline
\end{tabular}

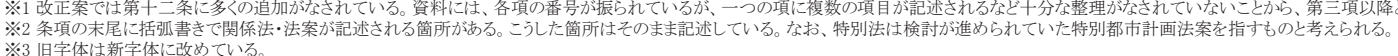


Table2 Draft of regional and urban planning law 地方計画及都市計画法案

\begin{tabular}{|c|c|c|}
\hline \multicolumn{3}{|r|}{$\begin{array}{cc}\text { 地方計画及都市計画法案 } \\
1945 \text { 年10月20日 }\end{array}$} \\
\hline \multirow{6}{*}{$\begin{array}{c}\text { 第一章 } \\
\text { 総則 }\end{array}$} & 第一条 & 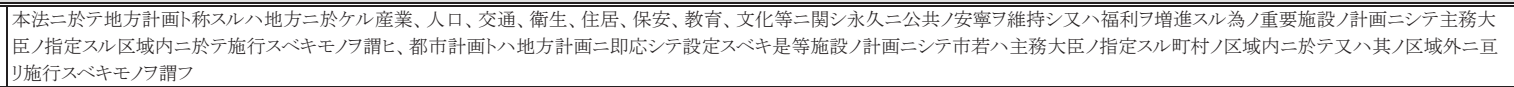 \\
\hline & 第二条 & $\begin{array}{l}\text { 主務大臣前条ノ規定二依少市若八主務大臣ノ指定スル町村ノ区域外二亘リ都市計画习施行スル必要アリ卜認ムルトキハ関係市町村及都市計画委員会ノ意見引聞キ都市計画区域习決定スベ } \\
\text { シ }\end{array}$ \\
\hline & 第三条 & 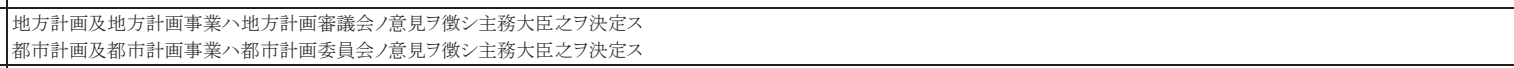 \\
\hline & 第四条 & 地方計画審議会及都市計画委員会/組織、権限及費用二関スル規定八勅令习以テ之ク定ム \\
\hline & 第五条 & 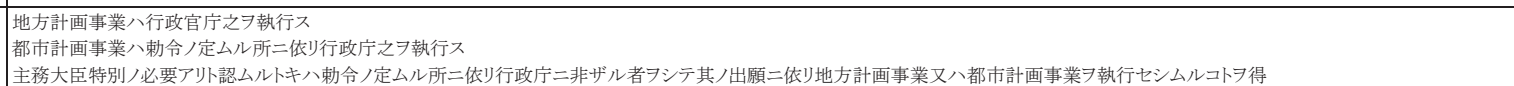 \\
\hline & 第六条 & 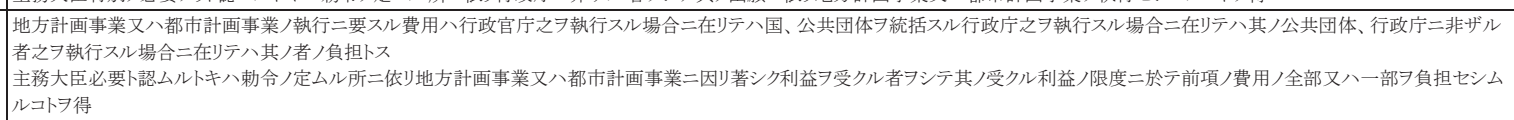 \\
\hline \multirow{14}{*}{$\begin{array}{l}\text { 第二章 } \\
\text { 土地ノ保全及 } \\
\text { 利用制限 }\end{array}$} & 第七条 & 主務大臣大都市ノ膨張ヨ抑制シ其ノ正常ナル発展ヨ図ル為必要卜認ムルトキハ地方計画区域内ニ於テ施設規制区域ヨ指定スルコトラ得 \\
\hline & 第八条 & 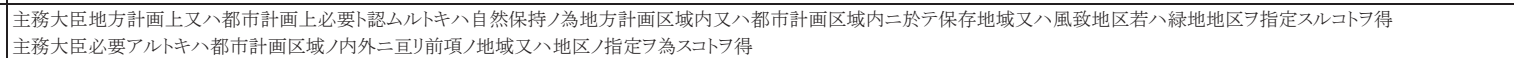 \\
\hline & 第九条 & 前二条ノ規定二依ル地域又ハ地区ノ指定アリタルトキハ勅令ノ定ムル所二依リ其ノ区域内二於ケル施設/設置、建築物ノ建築又ハ工作物ノ築造ヨ禁止シ又ハ制限スルコトラ得 \\
\hline & 第十条 & 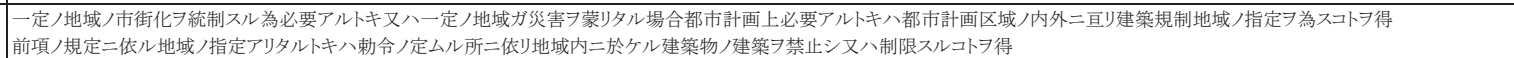 \\
\hline & 第十一条 & 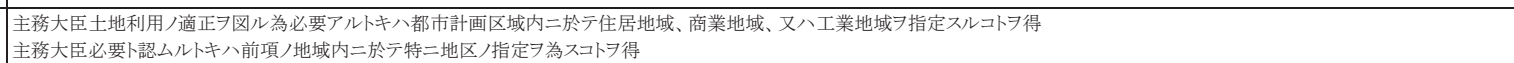 \\
\hline & 第十二条 & 主務大臣八都市計画上必要卜認ムルトキハ都市計画区域内二於テ高度地区、空地地区、防火地区、美観地区、其ノ他勅令ヨ以テ指定スル特別地区ヨ指定スルコトラ得 \\
\hline & 第十三条 & 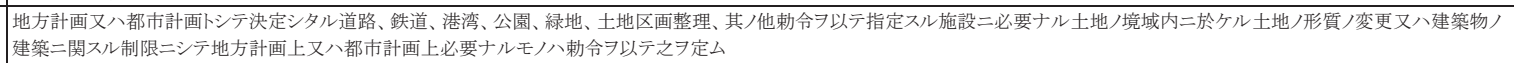 \\
\hline & 第十四条 & $\begin{array}{l}\text { 前条二規定スル施設ニ関スル地方計画事業又ハ都市計画事業ニ必要ナル土地八之ヨ収用又ハ使用スルコトラ得 } \\
\text { 前項土地附近ノ土地ニシテ地方計画事業又ハ都市計画事業トシテノ建築敷地造成二必要ナルモハハそラ収用又ハ使用スルコトラ得 }\end{array}$ \\
\hline & 第十五条 & 都市計画区域内二於テ第十三条第一項二掲グル施設ヨ造成セムトスルトキハ都市計画/施設トシテ之ヨ為スベシ \\
\hline & 第十六条 & 都市計画事業二依リ造成セラレタル広場、公園、緑地、墓苑、運動場、其/他勅令ヨ以テ定ムル施設ハ主務大臣/認可ヨ受クルニ非ザレバ之ラ廃止スルコトヨ得ズ \\
\hline & 第十七条 & 土地区画整理ノ為又八衛生上若八保安上/必要二依ル建築物/整理ノ為必要アルトキハ建築物其/他ノ工作物ヨ収用スルコトラ得 \\
\hline & 第十八条 & $\begin{array}{l}\text { 前二条ノ規定二依ル収用又ハ使用二関シテハ本法二別段ノ定アル場合ヨ除クノ外 土地収用法ヨ適用ス } \\
\text { 前項ノ規定二依ル土地収用法ノ適用二付テハ前条ノ工作物ハ之ヨ土地卜看做ス }\end{array}$ \\
\hline & 第十九条 & 第十四条又ハ第十五条ノ規定二依ル収用又八使用二付テハ第三条/規定二依ル地方計画又ハ都市計画/決定ヨ以テ土地収用法二依ル事業/認定卜看做又 \\
\hline & 第二十条 & 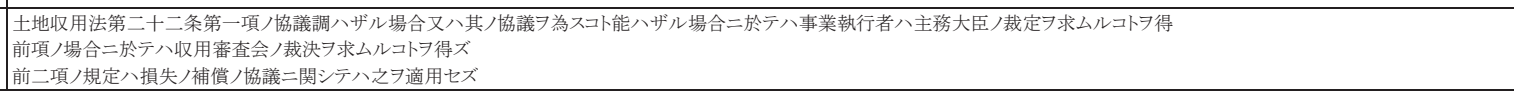 \\
\hline \multirow{10}{*}{\begin{tabular}{c|c|c|c|c|c|} 
第三章 \\
土地区画整理
\end{tabular}} & 第二十一条 & 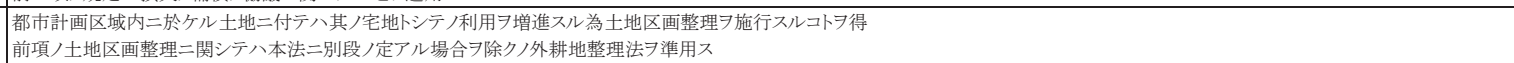 \\
\hline & 第二十二条 & 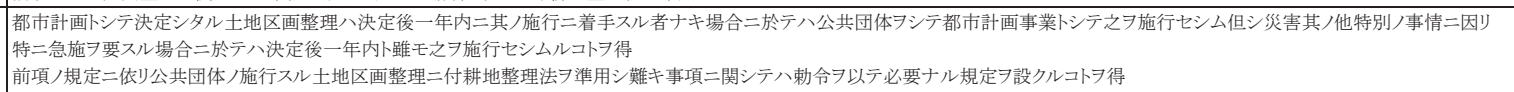 \\
\hline & 第二十三条 & 地方長官土地区画整理ノ設計二関スル認可ヨ為ス場合二於テハ主務大臣ノ認可ヨ受クベシ \\
\hline & 第二十四条 & 土地区画整理Э施行シタル土地/賃貸価格八勅令/定ムル所二依少光定ム \\
\hline & 第二十五条 & 土地区画整理二付テハ耕地整理法第四十三条ノ規定ニ拘ラズ建物アル宅地又八墳墓地ヨ土地区画整理施行地区二編入スルコトラ得 \\
\hline & 第二十六条 & 土地区画整理ノ施行二因リ道路、広場、公園、其ノ他公共ノ用二供スベキモハ為リタル土地八勅令ノ定ムル所二依リ国又ハ公共団体ノ所有地二之ラ編入ス \\
\hline & 第二十七条 & 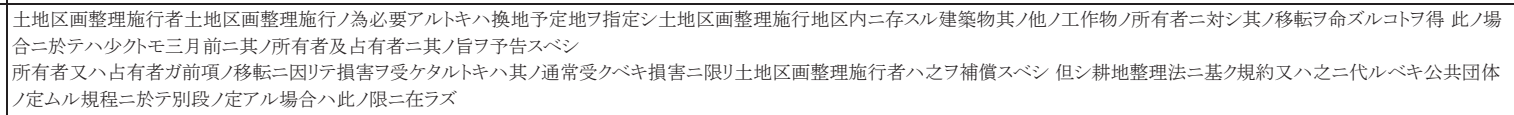 \\
\hline & 第二十八条 & 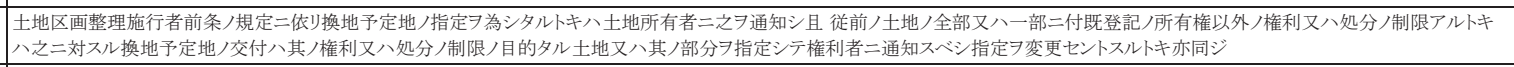 \\
\hline & 第二十九条 & 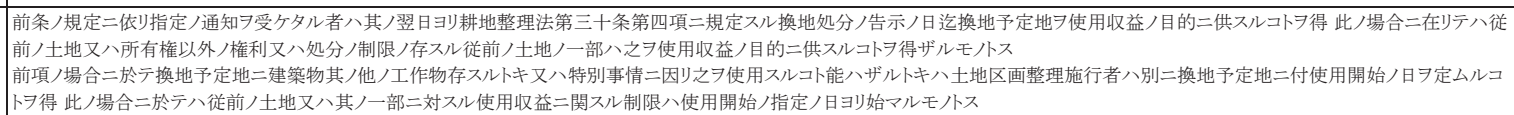 \\
\hline & 第三十条 & 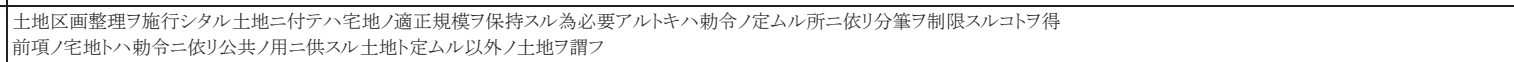 \\
\hline \multirow{7}{*}{$\begin{array}{c}\text { 第四章 } \\
\text { 雑則 }\end{array}$} & 第三十一条 & 都市計画区域内二存スル国有河岸地ニシテ公共ノ用二供セザルモノハ第六条ノ費用ヨ負担スル公共団体ニ之ヨ下付スルコトヨ得 \\
\hline & 第三十二条 & 第十四条第二項ノ規定二依リ収用シタル土地及前条/規定二依少下付ヨ受ケタル土地ノ処分及管理二関シテハ勅令ヨ以テ之ラ定ム \\
\hline & 第三十三条 & 地方計画事業又ハ都市計画事業二依リ生ジタル営造物ノ管理二付特二必要アル卜キハ勅令ノ定ムル所二依リ其ノ管理者习定ム \\
\hline & 第三十四条 & $\begin{array}{l}\text { 行政執行法第五条及第六条ノ規定並之二基キテ発スル命令八本法若八本法二基キテ発スル命令又ハ之ニ依リテ為ス処分二依リ行フベキ作為又ハ不作為ヨ行政庁ガ強制スル場合ニ之ヨ準 } \\
\text { 用ス }\end{array}$ \\
\hline & 第三十五条 & 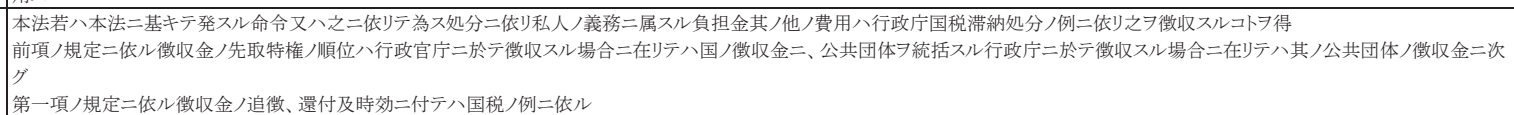 \\
\hline & 第三十六条 & $\begin{array}{l}\text { 本法又ハ本法二基キテ発スル命令二規定シタル事項二付行政庁ノ為シタル処分ニ不服アルモノハ訴願スルコトラ得 } \\
\text { 本法二依リ行政裁判所ニ出訴スルコトラ得ル場合二於テハ主務大臣ニ訴願スルコトラ得ズ }\end{array}$ \\
\hline & 第三十七条 & 本法又ハ本法二規定シタル事項二付行政庁ノ為シタル違法処分二因リ権利ラ毀損セラレタリトスル者ハ行政裁判二出訴スルコトラ得 \\
\hline \multirow{7}{*}{ 附則 } & 第三十八条 & 本法施行/期日ハ勅令ヨ以テ之ヨ定ム \\
\hline & 第三十九条 & 都市計画法八之ヨ廃止ス 但シ下付ᄏ受ケタル官有河岸地ノ地租/免除並二河岸地ヨリノ収入金及河岸地/売却譲与二関スル制限二関シテハ仍従前ノ例二依ル \\
\hline & 第四十条 & 都市計画法第一条ノ規定二依少指定ラ受ケタル町村八第一条ノ規定二依指定セラレタルモイ看做ス \\
\hline & 第四十一条 & 都市計画法第二条第二項/規定二依り決定セラレタル都市計画区域八第二条/規定二依り決定セラレタルモハ看做ス \\
\hline & 第四十二条 & 都市計画法第三条ノ規定二依リ内閣ノ認可ヨ受ケタル都市計画及都市計画事業八第三条ノ規定二依少決定セラレタルモハ看做ス \\
\hline & 第四十三条 & 都市計画法又ハ之二基キテ発シタル命令二依リ為シタル処分八本法又ハ本法二基キテ発スル命令ニ抵触セザル限リ本法二依リ為シタル処分卜看做ス \\
\hline & 第四十四条 & 防空法第五条/五ノ規定二依リ主務大臣/指定シタル地域及地区二付テ八勅令/定ムル所二依リ本法二依リ主務大臣/指定シタルモハ看做ス \\
\hline
\end{tabular}


表現となっているが、第一条において、

本法二於テ地方計画卜称スルハ地方二於ケル産業、人口、 交通、衛生、住居、保安、教育、文化等二関シ永久二公共 ノ安寧习維持シ又八福利ヨ增進スル為ノ重要施設ノ計画 ニシテ主務大臣ノ指定スル区域内ニ於テ施行スベキモノ ヨ謂イ、都市計画卜八地方計画二即応シテ設定スベキ是 等施設ノ計画ニシテ市若八主務大臣ノ指定スル町村ノ区 域内二於テ又八其ノ区域外二亘り施行スベキモノタ謂ウ

と記述されていることから、主務大臣が指定する区域内の全体計画 を地方計画とし、市区町村による具体的な計画を都市計画として区 分することが想定されている ${ }^{19)}$ 。これは、複数の都市・地域に渡る 計画や、都市間の調整等を念頭に置いた計画を地方計画として示そ うとしていた『戦災復興事業課題』の内容とも一致する。計画・事 業決定にあたっては、地方計画審議会と都市計画審議会を別に設け、 ここでの意見を経て決定を行うこととし(第三条)、事業執行も地方 計画については行政官庁が、都市計画については行政庁が執行する こととなっている(第五条)。このことから見ても、国・中央が中心 的に権限を持つ地方計画と、市区町村が権限を持つ都市計画を分け ることが必要とされている。こうした規定は、中央集中の都市計画 行政を改め、地方の地域性に即した都市づくりを進める意図と、都 市間の調整が戦前の都市計画上の大きな課題であったことを示して いる。また、多くの都市が臨む戦災復興事業の計画・事業実施を地 方行政がスムーズに執行できるようにする意図もあったと推察され る。

第二章は「土地ノ保全及利用制限/が名称付けられているように、 地域・都市に関する規制と事業実施に向けた規定がまとめられてい る。まず、都市計画区域とは別に地方計画区域を設定することとし ており、この区域では都市の膨張を抑制するための施設規制区域が 設定できるとされている。加えて、両地域に自然保護の観点から保 存地区、風致地区、緑地地区も指定できることとなっており、都市 周縁の地域・地区の建築規制や保護区域が設定できるように明確化 されている ${ }^{20)}$ 。また、こうした区域の施設対応を地方計画が扱うこ ととする考えであったことがわかる。先に検討されていた都市計画 法改正案と同様に、災害の被害にあった一定地域に建築規制地域を 指定できるとされているが、ここに「市街化习統制スル為必要アル」 場合が記されており、建築規制地域の市街地コントロールとしての 役割が明確にされている。

特徵的と言えるのは、第十一条で、都市計画区域内に住居地域、 商業地域、工業地域を指定することができるとしており、市街地建 築物法が担ってきたゾーニング制度を都市計画法に位置付けること が想定されている。これに加えて、高度地区、空地地区、防火地区、 美観地区、特別地区も指定可能とされており、市街地建築物法が担 っていた市街地コントロールについても、都市計画法が規定する積 極的な提案となっている ${ }^{211}$ 。すなわち、それまで建築法規が担った 集団規定を都市計画法にまとめる必要性が認識されていたのである。 第二章では、これに加えて、地方計画事業、都市計画事業の執行に 関する規定が示されている。

第三章は、土地区画整理の章として独立しており、土地区画整理
の為の法制定が必要で、これを包括的に都市計画法に組み込むこと が提案されている。これは、先の 2 つの都市計画法改正案と同様で もある。内容は事業の施行、手続き、土地価格や補償、土地の編入 など網羅的に整理がなされており、従前の耕地整理法や準備が進め られていた特別都市計画法を参照し、法文を整理していったのであ ろう。戦後の都市計画において土地区画整理事業を法的に位置付け る対応が必須であったことが窺える。

これに雑則・附則を加えた全四十四条が新たな時代の都市計画に 関する法案として作成された。

\section{4-2. 小結}

内務省では、都市計画法の改正にとどまらず、新たな計画単位と して地方計画を設定することを念頭に、この地方計画法と都市計画 法を統合して戦後の計画法として示す案が作成された。地方計画に ついて、明確な位置付けこそなされていないが、従来の都市計画の 対応できない都市間の調整や特定都市の無秩序な拡大をコントロー ルする内容を設定することが想定されており、こうした広域都市計 画を意味する地方計画と従来の都市計画とを関連付ける制度設計が 試案された。審查機関・事業執行についても地方計画と都市計画の 区分けが考えられており、中央主体の計画、地方自治体が主体の計 画・事業を重層的に設定する狙いがあったと読み取れる。

区域区分・地域地区の観点でみても、市街化の抑制、緑地の保全 双方から区域の設定が考えられており、市街地建築物法の用途地域 制も都市計画法内に設定するなど、市街地コントロールを地方計 画、都市計画を使い分けつつ、新たな法規案内に位置付けること が、戦後の都市計画行政及び法体系として重要と考えられたことが 窥える。また、新たな都市の計画法を検討するにあたって、土地区 画整理を進めるための条項を含めることが重要とされていた。これ は、当時の都市計画を進める上で必須の要件として、土地区画整理 が位置付けられていたと理解することができる。

\section{5. まとめ}

本稿では、終戦直後、戦災復興事業の準備が進められる中で思考 された内務省の都市計画法改正の動向把握を行なった。以下、その 特徵と意義を整理する。

内務省では、終戦を迎えたことで、戦前の都市計画課題を解決す るための項目整理が行われ、中央計画、地方計画、都市計画といっ た段階的な計画体系の構築と戦前の都市計画課題の解決による新た な都市づくりの必要性が認識されていた。法制面でも都市計画法の 改正とともに地方計画法の制定と戦災復興事業の実施に向けた特別 都市計画法制定といった複数の関連法を同時に検討することが必要 とされていた。

全国的な復興事業に向けて、基本方針、戦災復興計画標準、特別 都市計画法の検討といった準備が進められる中においても、都市計 画法の改正が重要であると認識され、具体的な法案づくりが進めら れることとなる。まずは、従前の都市計画法の必要部分の改正を進 めることが適切と考えられた。複数検討された改正案では、緑地地 区や工場規制区域といった新たな区域の設定や建築規制区域におけ る制限、土地区画整理事業の位置付けなど、戦災復興の目指す空間 像を実現するために必要な区域設定と事業推進を後押しする規定を 
都市計画法内に位置付けることが目指された。こうした事項は最低 限、戦前の都市計画法を改正する必要があった事項と位置付けられ る。また、こうした新たな区域設定や事業進捗による都市整備を非 戦災都市も対象に含む都市計画法に加えるとしたことは、戦災復興 事業のような土地区画整理による都市基盤整備・空間整備が戦後の 都市空間をつくる上で重要と認識されていたためであろう。

その後、都市計画法改正だけでなく、都市間の調整や、都市の拡 大に対応寸るための地方計画を加えた理想案の検討が行われること となった。この案では、各都市が主体的に計画・事業を進める都市 計画、都市間の計画など中央が主導して関与すべき地方計画を並列 に位置付けることが目指された。これに加えて、先の検討でもみら れた、事業進捗に向けた建築規制や土地区画整理の規定を設け、市 街地建築物法に規定されていた用途地域制を都市計画法内に位置付 けることを目指しており、総合的な市街地整備・コントロールを地 方計画と合わせた都市計画法が担う試案となっている。こうした案 が検討されたということは、戦前の無秩序なスプロール化と都市間 の関係整理が中央において大きな課題として認識されていたことを 表すとともに、都市間から建築に至るまでの一元的なコントロール の枠組みが、制度体系として必要であるとする思考が内務省内にあ ったことを意味している。加えて、地方計画を法制化する際、独自 の法制定ではなく、都市計画法と合わせた制定が適切と判断された ともいえる。以上のような、抜本的な法改正検討を都市計画行政が 先導して行ったのである。

その後の検討過程については、次稿に譲ることとしたい。

\section{追記}

本稿は、科学研究費助成事業 若手研究 $B$ 「戦後復興期における建 築・都市計画法規検討の体系的再解釈」(課題番号;17K14784)、基盤 研究 C「近現代都市計画・建築法制度の成立と変容をふまえた新時 代の制度体系構築に関する研究」（課題番号;18K04492）の成果の一 部である。

注

注1）内務省国土局計画課 : 戦災復興事業課題（1）, 1945 及び、内務省国土局 計画課 : 戦災復興事業課題（2）, 1945。なお、戦災復興事業課題（1）、 戦災復興事業課題（2）は同じ内容がまとめられている。

注2）主たるものとして、越澤明 : 復興計画, 中公新書, 2005、石田頼房 : 日本 近現代都市計画の展開 1868-2003, 自治体研究会, 2004 など。

注3）藤賀雅人：戦災都市土地利用計画設定標準の検討過程に対する考察, 日 本建築学会計画系論文集, 第 695 号, pp. 141-146, 2014. 1、藤賀雅人：小 宮賢一の戦災復興区画整理設計標準案について, 日本建築学会計画系論 文集, 第 681 号, pp. 2553-2560, 2012. 11 など

注4）藤賀雅人; 戦後「市街地建築物法改正」案の特徴と建築法要網試案 - 建 築法草案の検討過程に関寸る研究 その $1-$, 日本建築学会計画系論文集, 第 711 号, pp. 1147-1157, 2015. 5、藤賀雅人; 建築法規調查委員会の見解 と建築法案要綱 - 建築法草案の検討過程に関する研究 その $2-$, 日本建 築学会計画系論文集, 第 723 号, pp. 1153-1163, 2016.5 など。

注5）藤賀雅人 ; 宅地法検討に即した都市計画法改正案の内容と検討意義, 日 本建築学会計画系論文集, 第 732 号, pp. 443-450, 2017. 2 など。

注6）『地方計画法案・都市計画改正法案立案準備関係』は 1946（昭和 21） 年 7 月に設置された地方計画法案及び都市計画改正法案の基礎案作成 に向けた準備委員会の資料である。この準備委員会は、八嶋三郎計画課 長を委員長としており、委員は内務省計画課の技官を中心としつつも、 戦災復興院技官も加わり、顧問として伊東五郎戦災復興院監督課長等が 参加するなど、本格的な法改正に向けた検討であったことが窥える。『地 方計画法案・都市計画改正法案立案準備関係』には、準備委員会開催以
前に検討されていた都市計画法改正案、地方計画及都市計画法案等が収 録されるとともに、準備委員会にて検討された都市計画法改正の趣旨文、 委員会の検討を経て作成された施設計画法素案などが収められている。 なお、『地方計画法案・都市計画改正法案立案準備関係』内の資料は旧 字体・新字体が混じり、漢字・ひらがな表記の違いがある箇所も見られ るが、本稿では、新字体に統一し、その他の表記は資料の記述のまま用 いている。

注7）岡辺重雄 : 地方計画論の影響による戦前外地での地域制の発展と戦後都 市計画法改正検討, 都市計画論文集, Vol. 53, pp. 668-675, 2018

注8）阿部正隆, 西村幸夫, 䆶田亜矢: 戦前における内務省地方計画構想の一終 着点，都市計画論文集, Vol. 46, pp. 727-732, 2011

注9）この土地法については、地券発行や地価公定問題等が記載されているこ とから、戦災復興事業を進める上で検討されていた地券制度の法制化が 想定されていたと考えられる。なお、特別都市計画法については土地区 画整理と減歩率の記述がなされている。

注10) 前掲 1) 内務省国土局計画課（1945）

注11) 戦災復興事業の基本方針について、素案は、内務省国土局計画課; 戦災 地都市計画基本方針, 1945, 10、閣議決定された戦災復興都市計画基本方 針については、建設省; 戦災復興誌 第壱巻 計画事業編, 建設省, 1958 を 参照。戦災復興計画標準の検討過程については、藤賀雅人 : 戦災復興計 画標準の構築過程に関する研究, 明治大学博士学位論文, 2013 に詳しい。 注12）前掲 11) 内務省国土局計画課（1945）

注13）内務省国土局 : 都市計画法改正案, 1945.10.1、内務省国土局 : 都市計画 法改正案, 1945.10.2

注14)緑地地区、緑地地域と名称の違いこそ見られるが、同時期に検討されて いた地域地区設定標準案においても緑地地域が設定されており、大都市 に㧍ける市街地の連続を防止するための区域として位置付けられてい た。内務省国土局：地域地区設定標集案, 1945. 10

注15) 前掲 1) 内務省国土局計画課（1945）

注16）制定された特別都市計画法の内容及び検討過程の概略については、建設 省; 戦災復興誌 第参巻 法制編, 建設省, 1958 考参照。

注17）小画地一の対応については、前掲1)内務省国土局計画課（1945）におい て課題とされている他、土地区画整理設計標準の検討過程においても対 応の必要性が度々指摘されている。戦災復興土地区画整理設計標準の検 討過程については、前掲 3 ) 藤賀（2012）を参照。

注18) 戦災復興事業に向け、1946（昭和21）年 8 月 15 日には、戦災都市にお ける建築物の制限に関する勅令が示されている。こうした規定を都市計 画法内に位置付ける意図があったと推察される。

注19) 内務省国土局：地方計画及都市計画法案, 1945.10.20

注20)こうした都市周縁部に対する保全型区域、施設整備を規制する区域の設 定は、緑地地域の位置付けを検討する際にも議論となっている。また、 後に検討が進められた建築法草案の検討過程においても、都市周縁部に おいて保全型の区域、市街地拡大を抑制する区域、計画的な開発を進め る区域といった分割を行うことが提案されている。前掲 4) 藤賀 (2015, 2016)

注21）防火地区、高度地区、美観地区等は市街地建築物法に規定されていたも のであり、特別地区も戦災都市土地利用計画設定標準の検討過程におい て、建築物の用途形態、意匠等について特別の制限を地区毎に指定しな ければならない区域として想定されていた。前掲3)藤賀（2014） 


\section{A STUDY ON THE DELIBERATION PROCESS OF REVISE}

THE URBAN PLANNING LAW IN THE IMMEDIATE POSTWAR PERIOD PART 1:

BILL TO REVISE THE URBAN PLANNING LAW AND DRAFT OF REGIONAL PLANNING LAW IN 1945

\section{Masato FUIIGA*1 and Shigeo OKABE*2}

\footnotetext{
${ }^{* 1}$ Assoc. Prof., Dept. of Urban Design and Planning, School of Architecture, Kogakuin University, Ph.D.

${ }^{*}$ Prof., Dept. of Urban Management, School of Urban Management, Fukuyama City University, Ph.D. in Eng.
}

This paper studied the deliberation process of revise the urban planning law by the Home Ministry directly after World War II

As World War II came to an end, the Home Ministry organized items to solve prewar urban planning issues and realized the necessity to construct a phased planning system including central planning, regional planning and urban planning. From a legal system aspect, it was necessary to associate and discuss the multiple related laws including revisions of urban planning law, the enactment of regional planning law and the enforcement of special urban planning law aimed at war-damage reconstruction.

As preparations were underway for war-damage reconstruction, revisions of urban planning law were regarded as important. First, considerations were given to revisions of necessary parts in former urban planning law with the aim of placing regulations which support the creation of the ideal spatial image of postwar restoration such as establishing new zones as well as establishing construction regulations and land readjustment in urban planning law.

Afterwards, not only revisions of urban planning law, but also discussions about new bill that include regional planning which deals with the coordination between cities and the expansion of cities were conducted. This draft was to organize regional planning led by the central government and urban planning led by regional government, and to suggest a unified framework from the coordination between cities to architectural regulation. 